International Journal of Current Advanced Research

ISSN: O: 2319-6475, ISSN: P: 2319 - 6505, Impact Factor: SJIF: 5.995

Available Online at www.journalijcar.org

Volume 6; Issue 4; April 2017; Page No. 3214-3221

DOI: http://dx.doi.org/10.24327/ijcar.2017.3221.0229

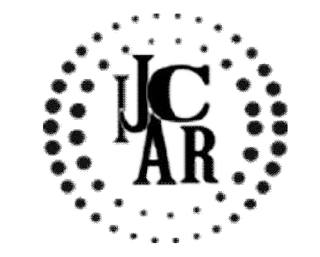

Research Article

\title{
THE ROLE OF PHILOSOPHY IN THE FIGHT AGAINST CORRUPTION IN CONTEMPORARY SOCIETY
}

\author{
Anthony Opiyo Ogutu*
}

South Eastern Kenya University, P. O. Box 170-90200, Kitui, KENYA

\begin{tabular}{l}
\hline A R T I C L E I N F O \\
\hline Article History: \\
Received $13^{\text {th }}$ January, 2017 \\
Received in revised form $19^{\text {th }}$ February, 2017 \\
Accepted $22^{\text {nd }}$ March, 2017 \\
Published online $28^{\text {th }}$ April, 2017 \\
\end{tabular}

Key words:

Corruption, Ethics, Education, Meaning, Philosophy, Value, Common Good, Person, Morality, Economics, Moral, Politics,

Democracy, Consent

\begin{abstract}
A B S T R A C T
There is nothing in the universe that does not interest or concern philosophy. Owing to the generality and vastness of its subject matter, philosophy is interested in the subject matter of all the other disciplines for philosophical reflection can be brought to bear on any subject matter whatsoever. In other words, every discipline raises questions which philosophical investigation can help clarify; and every domain of human existence confronts us with problems on which philosophical reflection can shed light such as issues to do with corruption, education, economics, law etc. Given that philosophy examines rationally the fundamental problems affecting man and the world in which he lives, it can contribute significantly in the fight against corruption particularly by addressing the phenomenon of corruption from a moral point of view given the fact that corruption is primarily an ethical or moral problem. This is to say that ethics deals with questions of morality- what is right and wrong in human relations. In other words, ethics is the philosophical study of morality and therefore we are saying that the impact of corruption has very serious ethical implications. Because ethical reflection illuminates an individual's sense of right and because there is a loss of sense of values in that contemporary society has obscured the one dimension of life which alone defines us as human-the ethical capacity for evaluating our conduct, this paper therefore proposes ethical awareness as the necessary condition in the fight against corruption since ethical awareness is the necessary condition for human survival and flourishing for without a basic moral norm that protects basic moral values, society itself is impossible. This paper therefore aims at shedding light on how philosophy can help in alleviating corruption by placing emphasis on the fundamental role of ethics. We can eradicate corruption completely by inculcating sound ethical moral values or by adopting an ethical culture given that ethics is derived from the Greek word ethos, meaning, custom, way of life, behavior, namely moral behavior. Besides, this paper also intends to point out why we cannot divorce philosophy from other disciplines such as education, economics, law etc. given that there is nothing in the universe which does not interest or concern philosophy.
\end{abstract}

Copyright $(2017$ Anthony Opiyo Ogutu. This is an open access article distributed under the Creative Commons Attribution License, which permits unrestricted use, distribution, and reproduction in any medium, provided the original work is properly cited.

\section{INTRODUCTION}

\section{Background to the Study}

The international conference organized by the Pontifical Council for Justice and Peace on the Theme "The Fight against Corruption" was held in the Vatican on 2-3 June 2006. The purpose of the conference was to arrive at a better understanding of the phenomenon of corruption, to identify the best methods for countering it and to explain the contribution that the church can make in this undertaking. Distinguished speakers, scholars, and experts on the phenomenon in question helped the participants gain insight into what corruption is and how to counter it at the global

*Corresponding author: Anthony Opiyo Ogutu

South Eastern Kenya University, P. O. Box 170-90200, Kitui, KENYA level, in the private sector, in the public sector, in civil society, in rich countries and in poor countries, depicting the harsh impact of this phenomenon on the poor people of the world and the characteristics of a culture of corruption. The phenomenon of corruption has always existed, nonetheless, it is only in recent years that awareness of it has grown at the international level. In fact, with regard to conventions on corruption and plans of action adopted by individual states and groups of states and by international organizations in the area of international trade, in the discipline of international commerce and especially in the field of finances, the majority of these efforts have been made in the last fifteen years. This means that corruption has only recently become recognized as a significant phenomenon and that a negative judgement of it is spreading at the worldwide level, while at the same time there is a growing awareness of the need to fight it. It is that document of the Pontifical Council for Justice and Peace on 
The Fight against corruption that elicited this study and since philosophy is a quest of wisdom, and whatever else wisdom may be, it is in some sense an understanding of life. It is not purely a cerebral attainment but it is as much a matter of what we do and feel as it is of how we think. Given that shoddy thought is expensive both in money and quality of life, philosophy examines rationally the fundamental problems affecting man and the world in which he lives. We have deemed it fit to employ philosophical reflection on the phenomenon of corruption because every sphere of human existence confronts us with problems on which philosophical reflection can shed light for we can only act rightly if and only if we think clearly since corruption has to do with our actions.

\section{Statement of the Problem}

Having said that philosophy examines rationally the fundamental problems affecting man and the world in which he lives and that philosophy is an attempt to clarify and if possible to give answers to certain puzzling and fundamental problems in our attempt to understand ourselves and the universe we inhabit, this paper is intended to show how philosophy can help in addressing the problem of corruption in such a fundamental and comprehensive manner since philosophy is the quest for wisdom and because thought is central to wisdom which is an affair of values, we can reiterate that the phenomenon of corruption stands in need of ethical orientation or consideration. Hegel, the German philosopher in his Phenomenology of the Spirit (1807) says that philosophy is getting clear about what we know and how to live. In his Encyclopedia of philosophical Sciences, Hegel begins his work by saying that "reflection, thinking things over- is the beginning of philosophy". We have pointed out in the abstract that every discipline raises questions that philosophical investigation or reflection can help clarify. In this regard, this paper therefore aims at employing philosophy to the phenomenon of corruption by showing how philosophy can help in shedding light on issues to do with corruption owing to the fact that the quality of our lives and that of what we build and produce depends ultimately on the quality of our thought. Shallowness, incompleteness, poor reasoning and assertions with flimsy foundations prevent a truly enlightened citizenry. Excellence in thought therefore must be systematically cultivated. In this regard, clear thinking or thinking critically contributes to right action. We can therefore reiterate the usefulness of philosophy by saying that philosophy plays a central part in any balanced college or university curricula. The study of philosophy contributes distinctly and substantially to the development of one's critical thinking. It enhances one's ability to deal rationally with normative issues. In fact, corruption is primarily a moral problem because it has to do with the rightness and wrongness of our actions. In other words, given that ethics, which is one of the traditional branches of philosophy deals with questions of morality- what is right and wrong in human relations, corruption as a phenomenon stands in need of an ethical orientation or consideration if at all we have to tackle it meaningfully. Philosophy therefore extends one's understanding of interdisciplinary questions. It strengthens our grasp of our intellectual history and of our culture in relation to others. It increases one'scapacity to articulate and assess world-views.

\section{Objectives of the Study}

This paper intends:

1. To Show how philosophy can help to clarify questions or problems raised in other disciplines such as education, economics, law etc.

2. To Shed light on how philosophical reflection, particularly moral considerations can help in the fight against corruption

3. To show why ethical awareness is the necessary condition for tackling corruption problems owing to the fact that ethics is concerned with principles, norms and ideal by which we ought to live or act

\section{RESULTS AND DISCUSSION}

\section{The Phenomenon of Corruption}

The phenomenon of corruption has always existed, nonetheless it is only in the recent years that awareness of it has grown at the international level. In fact with regard to conventions on corruption and plans for action adopted by individual states and by international organisations in the area of international trade, in the discipline of international commerce and especially in the field of finances, the majority of these efforts have been made in the last fifteen years.

The word corruption is derived from two Latin words; Com meaning "with, together" and rumpere meaning "to break, destroy". Thus engaging in corruption destroys one's worthiness and good reputation with others. In a nutshell, corruption is dishonest action that destroys peoples' trust. In other words, it refers to many different types of illegal acts, though usually all involve a person/groups abusing authority/power for their own benefits or for the benefit of family and friends. This could be government officials using money for their personal gains, or corporate executives improperly awarding contracts or taking other decisions in exchange for bribes. It is an unconscionable advantage, profit or gain of injustice, through the abuse of authority and power. Quora (2016) opines that corruption generally entails immoral human acts which are mainly beefed up by selfish motivations. For instance, a corrupt person could coil what is wrong to sound and appear right. This kind of behavior could as well be judged as due to lack of integrity and is one of the many characteristics of sophists. Quora argues that the more widespread and acceptable corrupt methods are in a given society, the more corrupt that society becomes.

In the document of the Pontifical Council for Justice and Peace entitled The Fight Against Corruption (2006), it is argued that corruption is a phenomenon that is not limited by politics or geography. It exists in rich countries and in poor countries. The economic impact of corruption is difficult to establish with precision, in fact, available data is often inconsistent. Nonetheless we are dealing with enormous amounts of resources that are taken away from the economy, from production and from social programmes. The costs are born by the citizens: The price of corruption is paid by using monies intended for the legitimate use of society. Besides, the Pontifical Council for Justice and Peace (2006) in their document the fight against corruption maintains that corruption crosses all social sectors: It cannot be attributed only to those who work in the economic sector or only to public officials; nor is civil society exempt. Corruption is a 
phenomenon that involves both individual states and international organisations.

A ready climate for corruption is fostered by a lack of transparency in international finances, by the existence of financial havens and by the disparity between the level at which corruption is fought- often limited to the level of single states- and the level at which corruption is carried out, usually at the supranational and international levels. It is also facilitated by limited cooperation between states in the fight against corruption, by the excessive differences in the norms of various legal systems, by the lack of media coverage of corruption in parts of the world, and by the lack of democracy in various countries. Without a free press, without democratic systems of checks and balances, without transparency, corruption is made that much easier.

Corruption is a cause of great concern today, in that it is also connected to drug-trafficking, to money-laundering, to the illegal trade of arms, and to other forms of criminality.

Corruption causes serious harm from a material point of view and places a costly burden on economic growth, still more harmful are its effects on immaterial goods, closely connected to the qualitative and human dimension of life in society. Political corruption, as the Compendium of the Social Doctrine of the Church teaches "compromises the correct functioning of the state, having a negative influence on the relationship between those who govern and the governed. It causes a growing distrust with respect to public institutions, bringing about a progressive disaffection in the citizens with regard to politics and its representatives, with a resulting weakening of institutions" (No. 411).

There is a very clear and empirically demonstrated connections between corruption and an absence of culture, between corruption and functional limitations of institutional systems, between corruption and the index of human development, between corruption and social injustices. This is not merely a process that weakens the economic system: corruption hinders the promotion of the person and makes societies less just and less open. In the Compendium of the Social doctrine of the Church, corruption is listed "among the causes that greatly contribute to underdevelopment and poverty" (No. 447) and sometimes it is also present within the very mechanisms by which aid is given to poor countries.

Corruption deprives peoples of a basic common good, that of legality: respect for rules, the correct functioning of economic and political institutions and transparency. Legality is truly a common good intended for everyone. In fact, it is a critical key to development, insofar as legality makes it possible to establish correct relationships between society, the economy and politics and insofar as it makes possible the framework of trust on which economic activity is based. The practice and the culture of corruption must be replaced by the practice and the culture of legality.

\section{Categories of Corruption}

Corruption manifests itself through various forms including petty and grand corruption, embezzlement of public funds and a system of political patronage, well entrenched within the fabrics of Society (Akpotor S., 2016). Concerning political corruption as the word political sounds, could refer to a politician who rather than letting the voters to decide who to vote for would bribe and steal his way into office. In other words, political corruption is the use of powers by government officials for illegitimate private gains. It is done under the cover of law or it involves trade influence, says the Transparency International (TI, 2016). For instance, the 2007 Post-Election violence in Kenya, which resulted into numerous deaths of over 1300 people, was due to corruption of extremely high rank. It was alleged that the incumbent president by then falsified the elections (Lafargue J., 2009)

Bribery is another form or category of corruption. This is the act of dishonestly persuading someone to act in one's favour by a payment of money or other inducement. Inducement can be in the form of gifts, loans, fees, rewards or other advantages. It is estimated that an average Kenyan citizen in urban centres, pays 16 bribes per month. Most of these bribes are fairly small but large ones are also taken. Bribes worth Kenya Shillings fifty thousand account for 41 percent of the total value. The use of bribe can lead to collusion like inspectors under-reporting offences in exchange for bribes or extortion such as bribes extracted against the threats of overreporting.

Since it is only those that are financially able who obviously pay bribes so that their needs to be met, it implies that most people especially those in rural areas, are left in an appalling and pathetic situations, or some are tempted to steal from the rich people in order to survive (Mutambo, A., 2016)

As far as business corruption is concerned, studies have shown that despite market reforms several business surveys reveal that business corruption is still widespread and that companies frequently encounter high demands for bribes and informal payments, for instance to get things done in Kenya. The public procurement sector suffers widespread corruption. The use of agents to facilitate business operations and transactions in Kenya is widespread and poses a risk for companies, particularly at the market entry and business startup stage (World Bank, 2016). For instance, there have been cases where goods tendered are paid for in full before any delivery. Even to make the matters worse, the prices of goods are allegedly inflated so that the additional money goes to the committee of the insider traders. In such situation, Anassi, P., (2004) points out that it is the government which suffers and in the long the citizens the citizens who pay taxes.

The pontifical Council for Justice and Peace in their document, The Fight against Corruption of 2006, maintained that "corruption crosses all social sectors". In this regard, there is no social sector which is spared from corruption. In this regard, we can also talk of corruption in learning institutions in particular in reference to Kenya. Corruption invades all sectors in Kenya today. Akpotor, S., (2016) argues that corruption pervades even the educational and religious sectors. Citing the work of Olorode, saying that "corruption as using one's position and power for personal gains, the governing council and university administrators have indeed come to epitomize corruption" (Olorode O., 2005). He goes on to say that Vice-chancellors and Principal Officers of universities are now reported to retire from their posts with horrendous severance perks (cars, money, air conditioners, etc.)

Similarly, the commercialization and deregulation of the religious sector have paved way for corruption on churches and church-related organisations. Incidents of sexual immorality and embezzlement of church funds have been 
reported. For instance, in some places priests have accepted bribes so as to remove the potent power of shrines in order to prevent the gods from acting against the culprit (Noonan, J.T., 1984). Aware of this potency, many of the corrupt public officers align themselves with spiritual or religious institutions to create a veneer of purity in the public eye.

\section{How philosophy cancontribute to the Fight against Corruption}

It is therefore of paramount importance to shed light on how philosophy can contribute to the fight against corruption in contemporary society owing to its nature as a discipline. In the background to the study, we pointed out that there is nothing in the universe that does not interest or concern philosophy and that every discipline raises questions which philosophical investigation can help clarify. We can therefore attest that given that philosophy examines rationally the fundamental problems affecting man and the world in which he lives and given that corruption crosses all the social sectors, philosophy can therefore address issues of corruption in such as fundamental and comprehensive manner having said that philosophical enterprise is essentially the application of reasoning to a wide variety of topics. In this regard, we intend to show how we can employ philosophy in tackling corruption issues. We cannot in anyway whatsoever divorce issues of corruption from philosophy just as we cannot divorce law, education, economics, politics and any other discipline from philosophy given that philosophy is the mother of all the other disciplines in terms of its object of study having said that philosophical reflection can be brought to bear on any subject matter whatsoever which in our case is corruption.

Since ethics is one of the traditional branches of philosophy and ethics deals with questions of morality- what is right and wrong in human relations, it is very vital to place emphasis on the fact that ethical reflection illuminates an individual's sense of right and that ethical awareness is the necessary condition for human survival and flourishing. Ethics is not only a descriptive science like other human or social sciences such as economics, psychology or sociology which are purely descriptive i.e. describing the human facts. On the contrary ethics is also a normative science concerned with principles, norms and ideals by which we ought to act or live. In this regards, what distinguishes ethics from other human social or human sciences is its oughtness. Given that corruption is predominately a moral or ethical problem because it has to do with our actions, it is important to lay stress on how ethics which is a branch of philosophy can help in addressing corruption as a phenomenon.

"Many keen observers have called attention to the loss of a sense of values that has accompanied the growth of modern technology (Muller, H.J., 1970). They tell us that we have been living under the illusion that more automobiles, laboursaving devices and the like will bring happiness and usher in a better life. Without a strong sense of values derived from value giving institutions such as family and religion and moral philosophy however, the human spirit tends to weaken or deteriorate. A number of scholars have argued that modern civilization is successful in transmitting to the young technical knowledge but fails to transmit moral, cultural and historical heritage of that civilization. John Edwin Smith, an experienced teacher and moral philosopher who has concern for contemporary society writes: "The most urgent problem of our time is posed by the awesome extent to which moral sensitivity and respect in the face of responsibility have eroded. The twin gospels of success and greed have literally dehumanized us by obscuring the one dimension of life which alone defines us as human- the ethical capacity for evaluating our conduct and for appraising our goals"(Smith, J.E. (1976). Smith goes on to say that it is very likely that economic needs and concerns have taken precedence over value questions. He maintains that in the modern world, institutions related to education, religion, science, the professions, recreation, business, government and the like have multiplied rapidly. They have a powerful influence over people and help to shape sentiments and standards of value. Although specialization brings benefits, specialists my see life in segments and give their attention to their own world, with or no concern about human welfare as a whole. Here comes moral philosophy or ethics to address the problem of corruption as a phenomenon that crosses all social sectors.

Today moral philosophers emphasise that an individual should transcend special interests and serve the larger society to which all persons belong.One of the basic and primary ways of alleviating corruption is by placing emphasis on what I may refer to as value theory. Value theory is the branch of philosophy that studies values. Value is derived from the Latin word valere, meaning to be of worth, that which is good, intrinsically good, good in itself. Value theory can be subdivided into ethics, aesthetics and social and political philosophy. I will focus on ethics and social and political philosophy because ethics deals with questions of moralitywhat is right and wrong in human relations and corruption as such has an enormous influence on the relation among human beings. As concerns political corruption, Social and political philosophy investigates value judgments concerning society, the state and the individual's relation to these institutions. The following questions reflect the concerns of social and political philosophy: "Why should individuals live in society? What social ideals of liberty, rights, justice, equality and responsibility are desirable? What criteria are to be used in determining who should have political power? Which criteria are to be used in determining the scope of political power, and what rights or freedoms should be immune from political or legal control? To what positive goals should political power be directed and what are the criteria for determining this? How can a democracy cope with concrete inequalities among its citizens?" (Titus et al, 1995). Such questions are worth posing when it comes to the issue of political corruption and they are questions of ethical nature owing to the fact that ethical reflection illuminates an individual's sense of right for we know that many practical obstacles stand between the democratic ideals of equality, freedom and the good life and their realization.

As regards the relation of power to authority, moral philosophers lay stress on consent in the establishment of authority. This is to say that "consent of the ruled is nowadays often viewed as a moral demand that must be met if the state is to possess legitimate authority and this is often taken to be a strong argument in favour of democracy" (Horner Chris and Westacott Emrys, 2000). In other words, the state has a contact with its citizens to deliver more freedom than they enjoyed in the state of nature. The state should do all it can to ensure that everyone enjoys the full benefits of freedom. This 
leads naturally to the idea that a further justification for the state's authority lies in its ability to promote the common good. In other words," there may be goals that the state should aim at for intrinsic, moral reasons, and not only because they promote freedom or security" (Horner Chris and Westacott Emrys, 2000)

As far as business corruption is concerned as discussed under the categories of corruption, philosophy has a lot to say in this domain, and to be specific in the sphere of business ethics. Moral philosophers take a special interest in right and wrong, good and bad, duty and obligation. When this interest is focused primarily on economic matters, on "business" in the widest sense, the examination is called business ethics. The economic impact of corruption is difficult to establish with precision. Moral Philosophers indeed have something to say in this regard by shedding light on the moral order of economy. They place emphasis on the basic and primary aim of any economic production. In other words, they lay stress on the supreme end of any economic enterprise. This is to say that Philosophy hasa lot to say in the domain of economics and one cannot therefore divorce philosophy from any economic discourse. Economic activity is of fundamental importance for the material conditions of human existence. However, philosophy goes deeper in addressing economic issues knowing that the economic impact of corruption is enormous in that we are dealing with enormous amount of resources that are taken away from economy, from production and social programmes. "The costs are borne by the citizens: the price of corruption is paid by using monies intended for the legitimate use of society" (Pontifical Council for Justice and Peace, 2006).

Scholars of economics for instance, have often refused moral considerations in the sphere of their science as an undue intrusion and usurpation. Economics, it is affirmed, is a science in its own right just as biology or medicine. Its fundamental task is the study of the laws that permit the optimum combination of means for the maximizing of the output together with the minimum use of scarce resources. In this task economy enjoys its own scientific autonomy and is independent of moral considerations. To a certain extent then, then, the aim of economic activity is profit. Economic liberalism, the maximizing of profit is even the supreme goal of efficient management. This is to say that the maximizing of profit as the highest criterion does not provide a barrier against the production of harmful products or of noxious commodities. It is not in a condition to secure a just wage if there is an excessive offer of work. It does not know boundaries against the destructive exploitation of the environment. Moral philosophers have rejected the above theorem that the fundamental purpose of economic activity should be "profit or prestige" (GS 64).

"Even though an economic enterprise must work profitably in order to survive and to develop and even though the striving after a reasonable profit remains legitimate, profit can only be a secondary purpose in economic enterprise" (Peschke, Karl H., 2004). Were it to be the primary purpose, this would inevitably bring many abuses and injustices in its train as proven by ample experience. An example of such an abuse is the scandals of 1988 surrounding the dumping of toxic wastes from Europe in African countries, which are not equipped to cope with them, but accepted them- pressured by financial needs at times for the ridiculous price of US dollars 2.5 per ton (Peschke, Karl H., 2004). Some of the wastes are highly poisonous to humans and nature and would require enormous sums to neutralize them.

Moral Philosophers therefore insist that this sphere of human activity, namely economics also stand in need of an ethical orientation. They maintain that economic activity is of fundamental importance for the material conditions of human existence. Many men and women are involved in it, in factory, field, office or shop and all depend on it. However, they argue that "the proper function of the economy is one of service" (Peschke Karl H., 2004). And it is here that moral evaluations come into play. In the static economy of a rural and pre-industrial society, the purpose of economic activity was to the greatest extent the satisfaction of the basic, material needs of people. This being the case, questions about further goals, criteria and norms appeared superfluous. Yet the dynamic economy of an industrial and post-industrial society definitely extends beyond the satisfaction of these most basic needs of people, and the question of its further goals poses itself with greater force. "It is to be retained that the objective of economy does not consist in mere profitability nor in the maximizing of the social produce or of the always greater material welfare of as many people as possible. All these are criteria of a utilitarian ethics, which cannot withstand a careful scrutiny in the light of the demands of universal justice.

What is therefore the authentic end of economy? The purpose of economic activity is the same as the purpose of human work. It is the constant teaching of the catholic social doctrine that the economy must be at the service of the person and not vice versa the person at the service of economy. Vatican II declares: The ultimate and basic purpose of economic production must be "the service of man, of man, that is, in his totality, taking into account his material needs and the requirements of his intellectual, moral, spiritual and religious life; of all men whomsoever and of every group of men of whatever race or from whatever part of the world" (GS 64). In a special way, attention must be given to the poor. Not that the supreme end of economy would be the service of the poor; this would be too narrow a definition. But the neglect of the poor is quite evidently a sign that an economic system does not resolutely stand at the service of God's resolute plan for humankind, which can be realized fully only if all men and women are enabled to contribute efficiently to it.

An economy paced at the service of the genuine needs of people can be summed up as an economy placed at the service of the common good. "The common good is the sum of those conditions of social living whereby men are enabled more readily and more fully to achieve their perfection and appointed ends" (GS 26; 74). The definition adds to the achievement of men's perfection that of their appointed ends, in as much as men have also the task to place themselves at the service of other people and of God's plan with the world. The functions of the common good are basically two:

First it promotes and makes possible an integral human existence for its members. In the realization of this goal, a person is helped by different societies, which all have their own common good in order to assist their members in the attainment of full humanity. Second, the common good is to preclude antisocial impulses in human nature from interfering 
with the rights of others and with the social order. This aspect of common good is realized by the establishment and securing of peace and order. The most efficient means to it is the law of the state, which has the power of coercion behind it (Peschke, Karl H., 2004)

The common good of a society is promoted by the members who belong to it. Theirs is the responsibility and obligation to respect and to advance it. The common good is therefore also an ethical enterprise. In this regard we can see the fundamental role played by philosophy in other fields of study and in this particular case in economics when it places emphasis on the need for ethical considerations in any kind of economic enterprise by pointing out that economic theories that maintain that economy should enjoy its own scientific autonomy and therefore should be independent of moral considerations are insufficient theories in that economic policies which cannot address the concrete needs of the human person are not worthwhile.

Moral philosophers also focus on the role of social entrepreneurs in the promotion of common good by making a clear cut distinction between social entrepreneurs and business entrepreneurs. In this regard, what distinguishes social entrepreneurs from business entrepreneurs? With this question, we arrive at the bedrock of social entrepreneurship: the ethics. "It is meaningless to talk about social entrepreneurs without considering the ethical quality of their motivation" (Bornstein, David, 2004). The why? "In the end business and social entrepreneurs are very much the same animals. They think about problems the same way. They ask the same types of questions. The difference is not in temperament or ability, but in the nature of their vision" (Bornstein, David, 2004). In other words, the ethical quality of social entrepreneurs' motivation distinguishes them from business entrepreneurs. Honesty in business affairs is a realm that indeed often leaves much to be desired, but that is also there is a moral postulate. We have previously pointed out that ethical reflection illuminates an individual's sense of right and that ethical awareness is the necessary condition for human survival and flourishing hence "without a basic moral code that protects basic moral values, society itself is impossible" (Pojman L.P., 2006). Yet many countries especially in Kenya seem to place more emphasis on science and technology in their millennium development than they place on the study of other disciplines. In order to achieve this they focus on science-oriented disciplines as opposed to the humanities and social sciences, so much so that the students who take science-related subjects are given more funding by comparison with students taking human and social sciences. "Yet this attitude of emphasizing science and technology at the expense of ethics is the source of so many crises in Africa, Kenya included. The main reason being that knowledge seems to have become divorced from values in our education curriculum in Africa" (Ogutu, Anthony, 2017). That is why we are convinced that a general account of the nature and object of ethical theory and philosophical reflection on morality is of paramount importance, without which an educated person cannot fully grasp the extent to which ethics and moral behavior can drive his own discipline or profession, and by extension, the development of a whole society. In other words, we can eradicate completely corruption by embracing an ethical culture. In this respect, there is a need to understand the importance of individual ethical reflection and the development of an individual's sense of right. It is equally important to establish a correlation between social and political crises due to rampant corruption cases in contemporary society and the lack of emphasis on ethics and to justify the need for the early introduction of ethics into educational curricula.

According to Wheelwright Philip, "ethics may be defined as that branch of philosophy which is the systematic study of reflective choice, of the standards of right and wrong by which it is to be guided, and of the goods toward which it may ultimately be directed". (Wheelwright Philip., 1959). As the ancient philosophers long ago discerned, philosophy is a quest for wisdom. "We all are aware that a person can have a great deal of knowledge and still be a learned fool" (Titus et al, 1995). In our age of confusion and uncertainty, we need a sense of direction. Wisdom is what provides us with that sense: it is an affair of values. As Abraham Kaplan has written regarding wisdom:

Whatever else wisdom may be, it is in some sense an understanding of life. It is not a purely cerebral attainment; wisdom is as much a matter of what we do and feel as it is of how we think. But thought is central to it... Wisdom is a matter of seeing things- but as they are, not subjectively (Kaplan Abraham, 1977)

Wisdom is intelligent conduct of human affairs. We experience intellectual discomfort when confronted with fragmentary and confused views of the world. Among other benefits, the study of philosophy gives our lives an inner integration, helps us to decide what to approve and what to disapprove, and provides a sense of the meaning of human existence. Having said that wisdom is an affair of values, we can also point out to the fact that "ethics is the philosophical study of voluntary actions with the purpose of determining which types of activity are good, right and to be done, or bad, wrong and not to be done, so that man may live well. It is generally regarded as a practical science in the sense that the objective of the study is not simply to know but to know which actions should be done and which should be avoided so as to translate knowledge into action" (Ogutu, Anthony, 2017) The subject of ethics is voluntary human conduct, including all actions and omissions over which man exercises personal control because he understands and wills these actions (and omissions) in relation to some end he has in view. What is aimed at in ethics is a reflective, well -considered and reasonable set of conclusions concerning the kinds of voluntary activities that may be judged good or suitable (or evil and unsuitable) for human agent in the context of man's life as a whole, including his relations to other beings whom his action influence in some significant way. In our case, it is corruption. For the economic impact of corruption is enormous. Ethics also include the relation of human actions to some overall goal of living: the knowing and loving of the perfect good, the higher welfare of the person or of his society, happiness or pleasure, or some such highest end.

\section{CONCLUSION AND RECOMMENDATIONS}

Having seen that the study of philosophy gives our lives an inner integration, helps us to decide what to approve and what to disapprove, and provides a sense of the meaning of human existence, it is also imperative to pinpoint that there is need to reflect on the place and role of ethics, which is a traditional 
branch of philosophy in the educational system in our contemporary era to enable education stakeholders to modify their approach by introducing ethics in our curriculum from the early school days. This early ethical reflection will illuminate an individual's sense of right among future generations if not the present generations. Hopefully students would begin to have a better understanding of the idea and meaning of moral values and the facts underlying ethical behavior. Ethical reflection can be integrated into any subject matter whether religion, anthropology, art, law, economics, business, education, politics etc. In fact the advocates of the ethical theory of the state maintain that it is inappropriate to divorce politics from ethics since the ultimate aim and function of the state is ethical.

When asked what good his philosophy did him, Aristotle, the ancient Greek philosopher remarked that it enabled him to do willingly what other people did merely because of fear of the law. A human being should through reasonbe able to discover the principles and the laws by which he or she should live by within society. This, according to Aristotle, is because natural laws are based on human nature and on the nature of societies. The behavior they prohibit is wrong not because a particular group or state has passed laws against them but because they run counter to the social nature of human beings. Since such laws are discoverable through reason, one who (through reason) has discovered such laws, in obeying the laws would be willingly obeying them whereas the individual who has not as yet discovered such laws, in obeying them would be doing so because of fear of retribution.

In his Nicomachean ethics, Aristotle argued that reason, wellbeing and moderation are central concepts. Just as the excellence of the sculptor lies in the skill with which she or he applies his art, so the excellence of humans lies in the fulfilment of their functions as human beings. The function peculiar to humans is their life of reason. They should live a life that fully actualizes their rational capacities, and by principles that best express what it means to be a human being. According to Aristotle, human action should aim at its proper end According to Aristotle, human action should aim at its proper end. Everywhere people aim at pleasure, wealth and glory. But none of these ends, although they have value, can occupy the place of the chief good for which we should aim. To be an ultimate end, an act must be self-sufficient and final-that which is always desirable itself and never for the sake of something else and it must be attainable. However, most of us are not really free because, most of the times, we lead unexamined lives: lives that we have not really thought about. We therefore engage in actions and behaviours merely on the basis of custom, tradition or the law, Individuals who fall within this category are, in a sense, machine-like: they are not significantly different from robots for indeed they are not really free. Philosophy is therefore a useful tool in emancipating one from all sort of bondage, be they cultural, historical, traditional or otherwise because a person who has studied philosophy is more likely to pursue an issue in depth, examine that issue comprehensively with sound reasoning than a person who has not studied philosophy. Philosophy is a quest of wisdom and wisdom is in some sense an understanding of life for it is not a purely cerebral attainment. It is as much a matter of what we do and feel as it is of how we think. However, it is crucial to note that thought is central to it for the quality of our lives and what we build or produce depends essentially on the quality of our thought. Jean Jacques Rousseau, a French Swiss political philosopher once said that to be a citizen is to want and to do what is good for oneself and for the society. We can therefore fight corruption by wanting to do what is good for ourselves and for the society at large.

It is worth noting as a matter of conclusion that every change begins with a vision and a decision to take action in the sense that change is brought about by action not mere wishes. We must do something to get out of our current situation. If we keep on doing what we have always done, then we will keep on getting what we have always got for we cannot use the same method and expect to get different results. When people work together, they are powerful; there is friendship. In the end, there is peace, harmony, tranquility, optimism. The study of philosophy contributes distinctly and substantially to the development of an individual's critical thinking. It enhances one's ability to deal rationally with normative issues. It strengthens one's grasp of our intellectual history and of our culture in relation to others. It enhances one's capacity to articulate and assess world views. Philosophical reflection can be brought to bear on any subject matter whatsoever such as corruption as a phenomenon for every discipline raises questions which philosophical investigation can help clarify and every domain of human existence confronts us with problems on which philosophical reflection can shed light. Because corruption is a moral problem, we therefore reiterate that ethical awareness is the necessary condition for eradicating corruption and because there is a lack of sense of values and lack of ethical sensitivity to evaluate our conduct, corruption has permeated all the spheres of our lives. In fact, the Pontifical Council for Justice and Peace (2006) in their document on the Fight against Corruption pointed out that corruption crosses all social sectors.

\section{References}

Akpotor S. (2016), "Corruption: The Civil Society and Government" in Corruption and Conflict in Africa, 58

American Philosophical Association (1980).The Role of Philosophy Programs in Higher Education. Newark: University of Delaware.

Amy, D. (1983).'Teaching the Moral Analysis of Policy Issues'. News for Teachers of Political Science, Winter Issue.

Bornstein, David (2004). How to Change the World: Social Entrepreneurs and the Power of New Ideas, Oxford: Oxford University Press.

C.D. Broad (1923), Scientific Thought, New York: Harcourt, Brace.

DeGeorge, R.T. (1990). Business Ethics. New York: Macmillan.

Flannery, Austine ed. (1975), Vatican Council II: The Conciliar and Post-Conciliar Documents, Vatican:

F. Ochieng - Odhiambo (1998), Handbook On Some Social-Political Philosophers, Nairobi: Consolata Institute of Philosophy Press

F. Ochieng- Odhiambo (2003), Introductory Symbolic Logic, Nairobi: Consolata Institute of Philosophy Press

F. Ochieng'-Odhiambo (2009), A Companion to Philosophy, Nairobi: Consolata Institute of Philosophy Press. 
Frederick C. Beiser ed. (1993) The Cambridge Companion to Hegel, Cambridge: Cambridge University Press.

G.W.F. Hegel, Encyclopedia of the Philosophical Sciences, Trans. W. Wallace, Oxford: Clarendon, 1975

G.W.F. Hegel (2001), The Philosophy of History, with Prefaces by Charles Hegel and the Translator, J. Sibree, M.A., Batoche Books, Kitchner.

Hegel Reason in History (1997), Translated by Robert Hartman, Library of Liberal Arts; Prentice-Hall Inc.

Horner Chris and Westacott Emrys, (2000), Thinking Through Philosophy: An Introduction, Cambridge: Cambridge University Press

Kant Immanuel (2002), Ground work for the Metaphysics of morals, edited and translated by Allen W. Wood, New Haven and London: Yale University Press.

Kaplan Abraham (1977), In Pursuit of Wisdom (Baverly Hills, California: Glencoe Press

Klinger I and Rimiru C. (2000), Philosophy, Science and God: An Introduction to Theodicy, Nairobi: Consolata Institute of Philosophy Press

Kuhn, J.W., \& Shriver, D.W. Jr. (1991). Beyond Success: Corporations and Their Critics in the 1990s. New York: Oxford University Press.

Lafargue J. (2009), The poling Debate in Kenya's 2007 Elections

Muller, H.J., (1970), The Children of Frankenstein: Modern Technology and Human Values, Bloomington: Indiana University Press.

Mutambo A. (2014), Analysis of ethics in the Fight against Corruption in Kenya
Njoroge, R.J., \&Bennaars, G.A. (1986). Philosophy and Education in Africa: An Introductory Text for Students of Education. Nairobi: Trans Africa.

Nyasani Joseph M. (2012), Cosmology: The Philosophy of Nature, Nairobi: Consolata Institute of Philosophy Press.

Ogutu, Anthony (2017), "Ethics in the Educational Curriculum in Africa”, in Tangaza Journal of Theology and Mission, 2016/I, Science and Religion

OriareNyarwath (2007), Traditional Logic: An Introduction, Nairobi: Consolata Institute of Philosophy Press

Peschke Karl H. SVD (2004), Christian Ethics: Moral Theology in the Light of Vatican II, Vol. II, Bangalore: Theological Publications

Plato (1952). Gorgias. New York: Liberal Arts Press.

Seibert, D.V. (1983, December 25). Time to Revive a Commitment to Ethics. New York Times.

Pojman, L.P. (2006). Ethics: Discovering Right and Wrong, Clare Hall: Cambridge University.

Shaw, W. H., \& Barry, V. E. (1992). Moral Issues in Business, $5^{\text {th }}$ ed. Belmont, CA: Wadsworth.

Smith, J.E. (November 1976), "In A Responsible Animal”, Yale Alumni Magazine and Journal

Titus, H. H., Smith, M. S., \& Nolan, R. T. (1995). Living issues in philosophy. New York: Wadsworth Publishing Company.

Whitehead, A. N. (1929). The Aims of Education. New York: Macmillan.

William, W. A. (1977). The Elements of Philosophy:A Compendium for Philosophers and Theologians. New York: Alba House.

\section{How to cite this article:}

Anthony Opiyo Ogutu (2017) ' The Role Of Philosophy In The Fight Against Corruption In Contemporary Society', International Journal of Current Advanced Research, 06(04), pp. 3214-3221.

DOI: http://dx.doi.org/10.24327/ijcar.2017.3221.0229 